\title{
Soft Magnetic Properties of Nanocystalline Fe-Si-B-Nb-Cu Rod Alloys Obtained by Crystallization of Cast Amorphous Phase
}

\author{
Akihisa Inoue $^{1}$, Baolong Shen ${ }^{2}$ and Tetsu Ohsuna ${ }^{1}$ \\ ${ }^{1}$ Institute for Materials Research, Tohoku University, Sendai 980-8577, Japan \\ ${ }^{2}$ Inoue Superliquid Glass Project, ERATO, Japan Science and Technology Corporation, Sendai 982-0807, Japan
}

\begin{abstract}
An amorphous alloy rod of $0.5 \mathrm{~mm}$ in diameter was produced for an $\mathrm{Fe}_{72.5} \mathrm{Si}_{10} \mathrm{~B}_{12.5} \mathrm{Nb}_{4} \mathrm{Cu}_{1}$ alloy by copper mold casting, though the maximum diameter of $1.5 \mathrm{~mm}$ for $\left(\mathrm{Fe}_{0.75} \mathrm{Si}_{0.1} \mathrm{~B}_{0.15}\right)_{96} \mathrm{Nb}_{4}$ alloy decreased by the addition of 1 at $\% \mathrm{Cu}$ and the decrease in $\mathrm{B}$ content. The amorphous alloy rod crystallizes through multi-stage exothermic reactions. The first exothermic peak is due to the precipitation of nanoscale bcc-Fe phase and the following exothermic peaks result from the transition of bcc-Fe+amorphous $\rightarrow$ bcc- $\mathrm{Fe}_{2}+\mathrm{Fe}_{23} \mathrm{~B}_{6}+\mathrm{Fe}_{2} \mathrm{~B}+\mathrm{Fe}_{3} \mathrm{Si}+\mathrm{Fe}_{2} \mathrm{Nb}$. The bcc-Fe phase has a particle size of about $10 \mathrm{~nm}$ and its volume fraction is approximately $70 \%$ after annealing for $300 \mathrm{~s}$ at $883 \mathrm{~K}$. The alloy rod consisting of bcc-Fe and amorphous phases exhibits good soft magnetic properties, i.e., high saturated magnetic flux density of $1.21 \mathrm{~T}$, low coercive force of $1.8 \mathrm{~A} / \mathrm{m}$ and high initial permeability of 32000 . The good soft magnetic properties for the nanocrystalline $\mathrm{Fe}_{72.5} \mathrm{Si}_{10} \mathrm{~B}_{12.5} \mathrm{Nb}_{4} \mathrm{Cu}_{1}$ alloy in a rod form of $0.5 \mathrm{~mm}$ in diameter are encouraging for future development as a new type of nanocrystalline soft magnetic bulk material.
\end{abstract}

(Received June 12, 2002; Accepted August 8, 2002)

Keywords: iron-based alloy, cast amorphous alloy, nanocrystalline alloy rod, nanocrystallization, soft magnetic property

\section{Introduction}

It is known that bulk glassy alloys with diameters above $1 \mathrm{~mm}$ are formed in a number of multi-component alloy systems which can be divided into nonferrous and ferrous alloy groups. ${ }^{1-4)}$ The development of bulk glassy alloys was performed by nonferrous alloy systems, followed by ferrous alloy systems. When we focuss on Fe-based bulk glassy alloys, one can list the following alloy systems, i.e., $\mathrm{Fe}-(\mathrm{Al}, \mathrm{Ga})-(\mathrm{P}, \mathrm{C}, \mathrm{B}),{ }^{5)} \mathrm{Fe}-(\mathrm{Al}, \mathrm{Ga})-$ $(\mathrm{P}, \mathrm{C}, \mathrm{B})-(\mathrm{Cr}, \mathrm{Mo}, \mathrm{Co}),{ }^{6} \mathrm{Fe}-\mathrm{Ga}-(\mathrm{P}, \mathrm{C}, \mathrm{B}),{ }^{7)} \mathrm{Fe}-\mathrm{Ga}-(\mathrm{P}, \mathrm{C}, \mathrm{B})-$ $(\mathrm{Cr}, \mathrm{Mo}, \mathrm{Co}),{ }^{8-10)} \mathrm{Fe}-(\mathrm{Zr}, \mathrm{Hf}, \mathrm{Nb}, \mathrm{Ta})-\mathrm{B},{ }^{11)} \mathrm{Fe}-(\mathrm{Zr}, \mathrm{Hf}, \mathrm{Nb})-$ $\left.(\mathrm{Cr}, \mathrm{Mo}, \mathrm{W})-\mathrm{B},{ }^{12}\right) \mathrm{Fe}-\mathrm{Co}-\mathrm{Ln}$ (lanthanide metal)-B, ${ }^{13)} \mathrm{Fe}-$ $\left.\left.(\mathrm{Nb}, \mathrm{Cr}, \mathrm{Mo})-(\mathrm{P}, \mathrm{C}, \mathrm{B}),{ }^{14}\right) \mathrm{Fe}-(\mathrm{Cr}, \mathrm{Mo})-(\mathrm{B}, \mathrm{C}),{ }^{15}\right)$ Fe-Ni$(\mathrm{P}, \mathrm{B}),{ }^{16)} \mathrm{Fe}-\mathrm{Si}-\mathrm{B}-\mathrm{Nb}^{17)}$ and $\mathrm{Fe}-\mathrm{Si}-\mathrm{B}-\mathrm{Zr}^{18)}$ etc. All these Fe-based bulk glassy alloys exhibit a supercooled liquid region of 35 to $90 \mathrm{~K}$ before crystallization and the largest diameter is about 5 to $6 \mathrm{~mm}$ for $\mathrm{Fe}-(\mathrm{Zr}, \mathrm{Nb}, \mathrm{Ta})-(\mathrm{Mo}, \mathrm{W})-\mathrm{B}$ system. ${ }^{19)}$ In addition, almost all Fe-based bulk glassy alloys exhibit ferromagnetism at room temperature and the saturated magnetic flux density $\left(B_{\mathrm{S}}\right)$ is in the range from 1.2 to $1.4 \mathrm{~T}$ for $\mathrm{Fe}-\mathrm{Ga}-(\mathrm{P}, \mathrm{C}, \mathrm{B}),{ }^{5)} \mathrm{Fe}-\mathrm{Co}-\mathrm{Ln}-\mathrm{B}^{20)}$ and $\mathrm{Fe}-\mathrm{Ga}-(\mathrm{P}, \mathrm{C}, \mathrm{B}, \mathrm{Si})^{21)}$ alloys. It has subsequently been found that the $B_{\mathrm{s}}$ exceeds $1.5 \mathrm{~T}$ for $\mathrm{Fe}-\mathrm{Si}-\mathrm{B}-\mathrm{Nb}^{17)}$ and $\mathrm{Fe}-\mathrm{Si}-\mathrm{B}-\mathrm{Zr}^{18)}$ alloys. The bulk glassy alloys in $\mathrm{Fe}-\mathrm{Si}-\mathrm{B}-\mathrm{Nb}$ and $\mathrm{Fe}-\mathrm{Si}-\mathrm{B}-\mathrm{Zr}$ systems are very attractive as a new type of soft magnetic bulk alloy. Thus the bulk glassy alloys with good soft magnetic properties were developed in a number of Fe-based multi-component systems. However, there have been no data on the synthesis of a nanocrystalline Fe-based bulk alloy with good soft magnetic properties. Very recently, we have found that a cast amorphous alloy rod with a diameter of $0.5 \mathrm{~mm}$ is also formed in $\mathrm{Fe}-\mathrm{Si}-\mathrm{B}-\mathrm{Nb}-\mathrm{Cu}$ system and the subsequent annealing causes the formation of a nanostructure consisting of nanoscale bccFe particles surrounded by the remaining amorphous phase, accompanying the appearance of good soft magnetic proper- ties. This paper intends to present the alloy composition at which an amorphous alloy rod is formed in $\mathrm{Fe}-\mathrm{Si}-\mathrm{B}-\mathrm{Nb}-\mathrm{Cu}$ system by copper mold casting as well as the relation between partially crystallized structure and magnetic properties for the bulk amorphous alloys.

\section{Experimental Procedure}

Multi-component Fe-based alloy ingots with composition of $\mathrm{Fe}_{95-x-y} \mathrm{Si}_{x} \mathrm{~B}_{y} \mathrm{Nb}_{4} \mathrm{Cu}_{1}$ were prepared by arc melting the mixtures of pure $\mathrm{Fe}, \mathrm{Nb}$ and $\mathrm{Cu}$ metals, pure silicon and crystal boron in an argon atmosphere. The alloy compositions represent the nominal atomic percentages. From the alloy ingots, alloy rods with different diameters up to $2 \mathrm{~mm}$ were produced at an ejection pressure of $0.2 \mathrm{MPa}$ by the copper mold casting method. Alloy ribbons were also produced for comparison by the melt spinning method. The crystallization process of the amorphous alloys was determined by differential scanning calorimetry (DSC) at a heating rate of $0.67 \mathrm{~K} / \mathrm{s}$. The as-quenched and annealed samples were examined with an X-ray diffractometer with $\mathrm{Cu} \mathrm{K} \alpha$ and $\mathrm{Cr} \mathrm{K} \alpha$ radiation (XRD), respectively. The nanocrystalline structure of the ribbon and bulk samples after annealing was observed by a transmission electron microscope (TEM) operating at $400 \mathrm{keV}$ linked with selected area electron diffraction. The composition of the bcc phase for the ribbon and bulk samples annealed under optimal conditions was examined by highresolution transmission electron microcopy (HRTEM) combined with energy-dispersive spectroscopy (EDS) analyses. Liquidus and solidus temperatures were determined by differential thermal analysis (DTA). Magnetic properties of saturated magnetic flux density $\left(B_{\mathrm{s}}\right)$ and coercive force $\left(H_{\mathrm{c}}\right)$ were measured with a vibrating sample magnetometer (VSM) under a maximum applied magnetic field of $400 \mathrm{kA} / \mathrm{m}$ and with an DC B-H loop tracer under a magnetic field up to $800 \mathrm{~A} / \mathrm{m}$, respectively. The permeability $\left(\mu_{\mathrm{i}}\right)$ at $1 \mathrm{kHz}$ under $0.8 \mathrm{~A} / \mathrm{m}$ 
was measured with an AC B-H loop analyzer.

\section{Results}

Figure 1 shows the $\mathrm{X}$-ray diffraction pattern of the cast $\mathrm{Fe}_{72.5} \mathrm{Si}_{10} \mathrm{~B}_{12.5} \mathrm{Nb}_{4} \mathrm{Cu}_{1}$ alloy rod of $0.5 \mathrm{~mm}$ in diameter and about $30 \mathrm{~mm}$ in length obtained by XRD with $\mathrm{Cu}$ $\mathrm{K} \alpha$ radiation, together with the data of the corresponding melt-spun alloy ribbon. In addition, the data of the cast $\left(\mathrm{Fe}_{0.75} \mathrm{Si}_{0.1} \mathrm{~B}_{0.15}\right)_{96} \mathrm{Nb}_{4}$ alloy rod of $1.5 \mathrm{~mm}$ in diameter and $50 \mathrm{~mm}$ in length are also shown for comparison. Only broad peaks are seen for all the samples, indicating the formation of an amorphous phase in the rod diameter range up to $0.5 \mathrm{~mm}$ for the $\mathrm{Fe}_{72.5} \mathrm{Si}_{10} \mathrm{~B}_{12.5} \mathrm{Nb}_{4} \mathrm{Cu}_{1}$ alloy and $1.5 \mathrm{~mm}$ for the $\left(\mathrm{Fe}_{0.75} \mathrm{Si}_{0.1} \mathrm{~B}_{0.15}\right)_{96} \mathrm{Nb}_{4}$ alloy. The glass-forming ability is significantly reduced by the addition of $1 \mathrm{at} \% \mathrm{Cu}$ as well as by the decrease of B content. Such a modification of alloy composition is attributed to the synthesis of $\mathrm{Fe}-\mathrm{Si}-\mathrm{B}-\mathrm{Nb}$ base alloy with multi-stage crystallization mode. Figure 2 shows the DSC curves of the $\mathrm{Fe}_{72.5} \mathrm{Si}_{10} \mathrm{~B}_{12.5} \mathrm{Nb}_{4} \mathrm{Cu}_{1}$ alloy in ribbon and rod $(0.5 \mathrm{~mm}$ in diameter) forms together with the data of the $\left(\mathrm{Fe}_{0.75} \mathrm{Si}_{0.1} \mathrm{~B}_{0.15}\right)_{96} \mathrm{Nb}_{4}$ alloy rod of $1.5 \mathrm{~mm}$ in diameter. The latter $0 \% \mathrm{Cu}$ alloy rod exhibits a sequent change in glass transition, supercooled liquid and then crystallization. On the other hand, the former $1 \% \mathrm{Cu}$-containing alloy exhibits distinctly separated exothermic peaks, indicating that the crystallization proceeds through at least two stages in the absence of the supercooled liquid state. The temperature interval between the main two exothermic peaks is as large as $105 \mathrm{~K}$. The multi-stage crystallization mode is in agreement with that for the $\mathrm{Fe}_{73.5} \mathrm{Si}_{13.5} \mathrm{~B}_{9} \mathrm{Nb}_{3} \mathrm{Cu}_{1}$ (FINEMET) alloy ${ }^{22)}$ with differ-

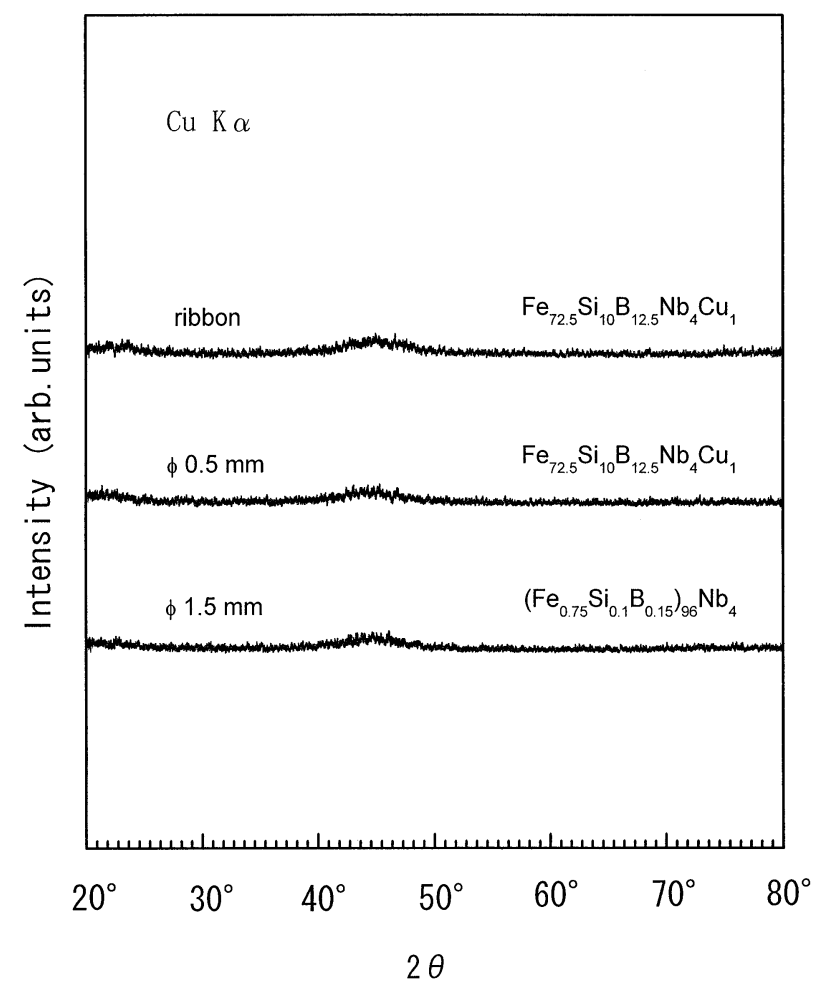

Fig. 1 X-ray diffraction pattern of a cast $\mathrm{Fe}_{72.5} \mathrm{Si}_{10} \mathrm{~B}_{12.5} \mathrm{Nb}_{4} \mathrm{Cu}_{1}$ alloy rod with a diameter of $0.5 \mathrm{~mm}$. The data of the corresponding melt-spun amorphous alloy ribbon and a cast $\left(\mathrm{Fe}_{0.75} \mathrm{Si}_{0.1} \mathrm{~B}_{0.15}\right)_{96} \mathrm{Nb}_{4}$ glassy alloy rod with a diameter of $1.5 \mathrm{~mm}$ are also shown for comparison.

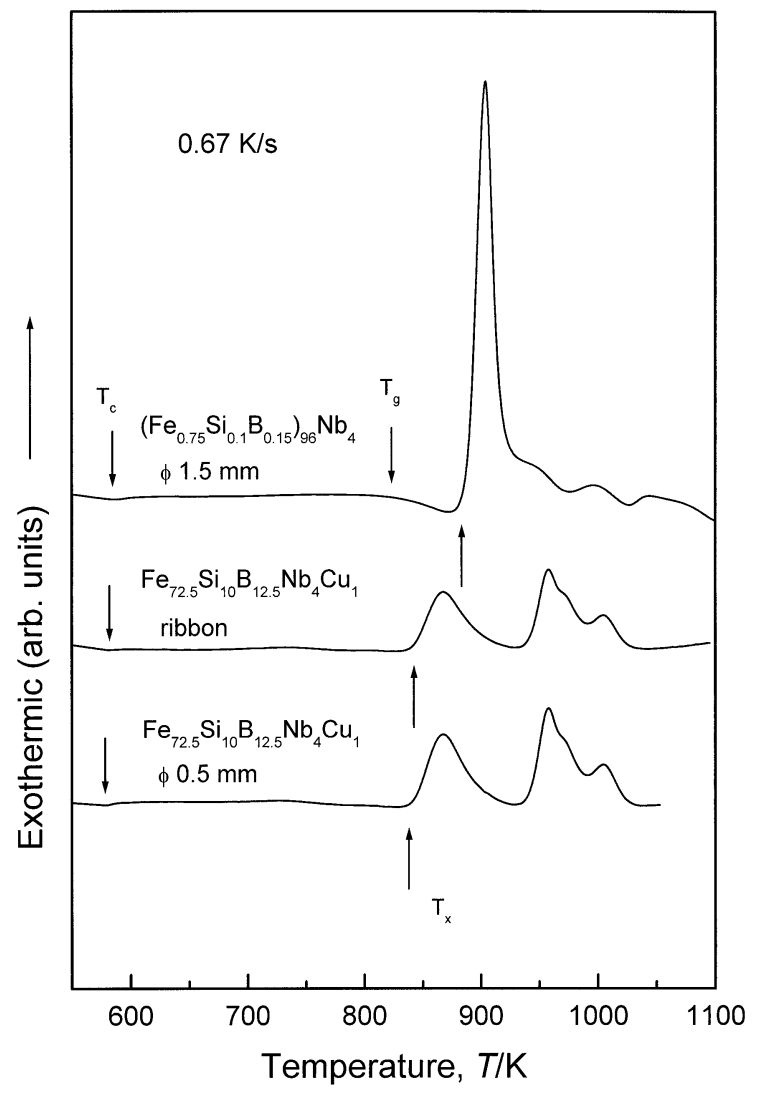

Fig. 2 DSC curves of the $\mathrm{Fe}_{72.5} \mathrm{Si}_{10} \mathrm{~B}_{12.5} \mathrm{Nb}_{4} \mathrm{Cu}_{1}$ amorphous alloys in a ribbon and rod $(0.5 \mathrm{~mm}$ in diameter $)$ forms. The data of the $\left(\mathrm{Fe}_{0.75} \mathrm{Si}_{0.1} \mathrm{~B}_{0.15}\right)_{96} \mathrm{Nb}_{4}$ glassy alloy rod with a diameter of $1.5 \mathrm{~mm}$ are also shown for comparison.

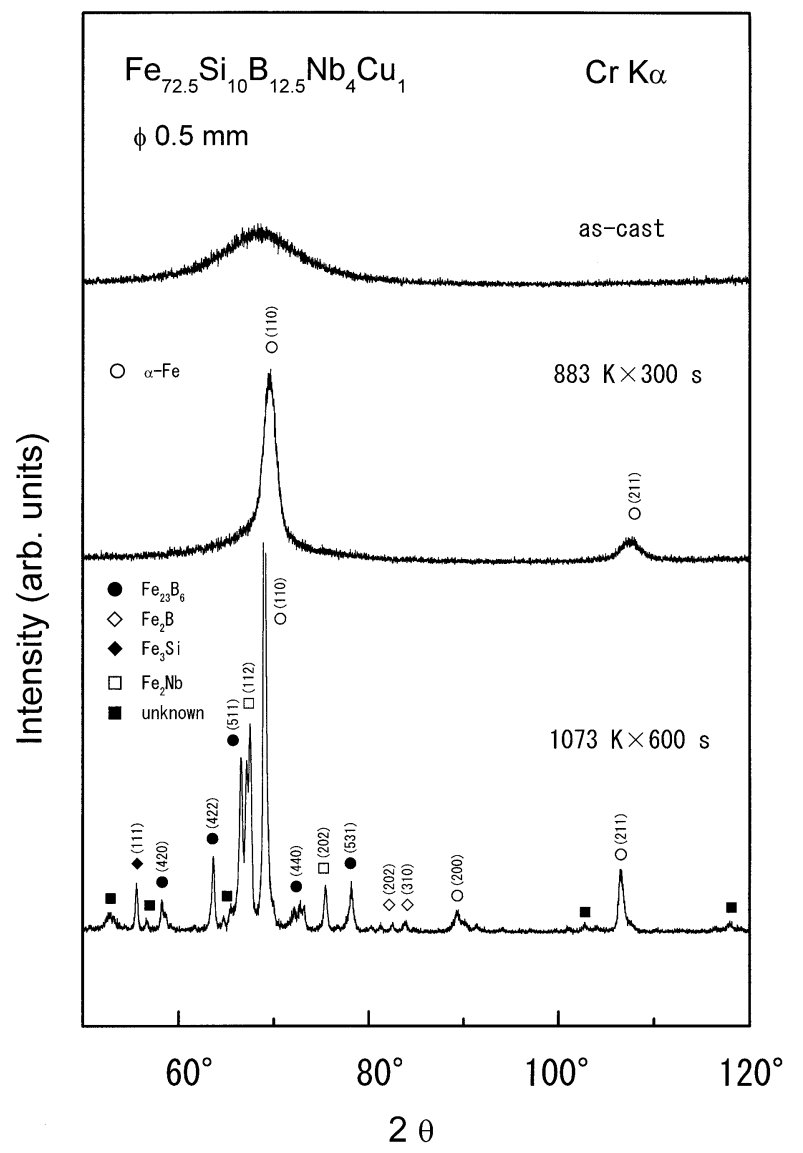

Fig. 3 X-ray diffraction patterns of the $\mathrm{Fe}_{72.5} \mathrm{Si}_{10} \mathrm{~B}_{12.5} \mathrm{Nb}_{4} \mathrm{Cu}_{1}$ amorphous alloy rod with a diameter of $0.5 \mathrm{~mm}$ annealed for $300 \mathrm{~s}$ at $883 \mathrm{~K}$ and $600 \mathrm{~s}$ at $1073 \mathrm{~K}$. 
ent metalloid and $\mathrm{Nb}$ contents. Here, it is important to point out that the use of the FINEMET alloy does not produce any amorphous phase by the copper mold casting method, being consistent with the previous data. ${ }^{22}$

The crystalline phases during the two-stage exothermic reactions were examined by $\mathrm{XRD}$ with $\mathrm{Cr} \mathrm{K} \alpha$ radiation and TEM. The reason for the use of $\mathrm{Cr} \mathrm{K} \alpha$ radiation here is because of large absorption ability of $\mathrm{Cu} \mathrm{K} \alpha$ radiation for $\mathrm{Fe}$. Figure 3 shows the X-ray diffraction patterns of the $1 \% \mathrm{Cu}$ containing alloy rod annealed for $300 \mathrm{~s}$ at $883 \mathrm{~K}$ and $600 \mathrm{~s}$ at $1073 \mathrm{~K}$ corresponding to the peak temperatures of the firstand third-exothermic peaks, respectively. The X-ray diffraction patterns are identified as bcc-Fe + amorphous phases for the former sample and bcc-Fe $+\mathrm{Fe}_{23} \mathrm{~B}_{6}+\mathrm{Fe}_{2} \mathrm{~B}+\mathrm{Fe}_{3} \mathrm{Si}+$ $\mathrm{Fe}_{2} \mathrm{Nb}$ phases for the latter sample, indicating that the crystallization reaction proceeds in the multi-stage process including the primary precipitation phase of bcc-Fe even for the rod sample. Figure 4 shows bright- and dark-field TEM images and selected-area electron diffraction of the mixed bcc-Fe and amorphous phases in the rod sample. It is seen that bcc-Fe grains with a particle size of about $10 \mathrm{~nm}$ disperse homoge- neously in a surrounded state by the remaining amorphous phase. The nanobeam EDX data were taken from ten particles of the bcc-Fe phase. The average analytical compositions except B were 82.3 at $\% \mathrm{Fe}, 13.7 \mathrm{at} \% \mathrm{Si}, 2.7 \mathrm{at} \% \mathrm{Nb}$ and $1.3 \mathrm{at} \% \mathrm{Cu}$. It is clearly confirmed that $\mathrm{Si}$ element is enriched into the bcc-Fe phase while $\mathrm{Nb}$ element is rejected. The similar tendency is also obtained in the $\mathrm{Fe}_{73.5} \mathrm{Si}_{13.5} \mathrm{~B}_{9} \mathrm{Nb}_{3} \mathrm{Cu}_{1}$ ribbon alloy. ${ }^{23,24)}$ The decrease in $\mathrm{Si}$ content and the increase in $\mathrm{Nb}$ content in the remaining amorphous phase cause an increase in the thermal stability of the remaining amorphous phase, in conjunction with the nanoscale bcc-Fe particles.

Table 1 summarizes thermal stability and soft magnetic properties of the nanocrystalline $\mathrm{Fe}_{72.5} \mathrm{Si}_{10} \mathrm{~B}_{12.5} \mathrm{Nb}_{4} \mathrm{Cu}_{1}$ alloy rod consisting of the mixed bcc-Fe and amorphous phases obtained by annealing the cast amorphous alloy rod for $300 \mathrm{~s}$ at $883 \mathrm{~K}$. The data of the nanocrystalline $\mathrm{Fe}-\mathrm{Si}-\mathrm{B}-\mathrm{Nb}-\mathrm{Cu}$ alloy ribbon obtained by the same annealing treatment are also presented for comparison. It is noticed that the nanocrystalline alloy rod exhibits good soft magnetic properties, i.e., a high saturated magnetic flux density $\left(B_{\mathrm{s}}\right)$ of $1.21 \mathrm{~T}$, a low coercive force $\left(H_{\mathrm{c}}\right)$ of $1.8 \mathrm{~A} / \mathrm{m}$ and a high initial permeability $\left(\mu_{\mathrm{i}}\right)$ of

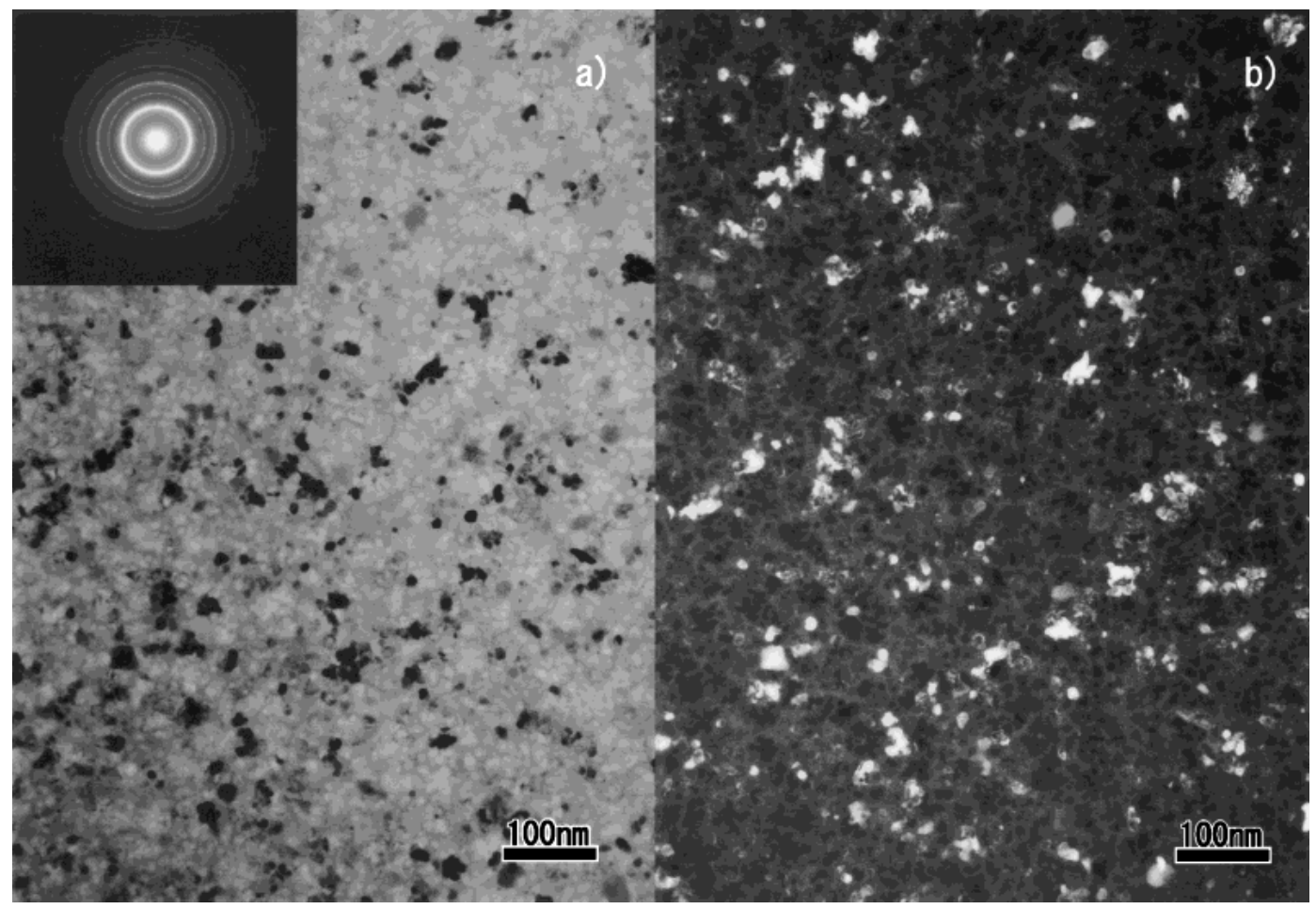

Fig. 4 Bright- and dark-field TEM images (a and b) and selected-area electron diffraction pattern of the $\mathrm{Fe}_{72.5} \mathrm{Si}_{10} \mathrm{~B}_{12.5} \mathrm{Nb}_{4} \mathrm{Cu}_{1}$ amorphous alloy rod with a diameter of $0.5 \mathrm{~mm}$ annealed for $300 \mathrm{~s}$ at $883 \mathrm{~K}$.

Table 1 Thermal stability and soft magnetic properties of the $\mathrm{Fe}_{72.5} \mathrm{Si}_{10} \mathrm{~B}_{12.5} \mathrm{Nb}_{4} \mathrm{Cu}_{1}$ alloy rod with a diameter of $0.5 \mathrm{~mm}$ annealed for $300 \mathrm{~s}$ at $883 \mathrm{~K}$. The data of the as-cast glassy $\left(\mathrm{Fe}_{0.75} \mathrm{Si}_{0.1} \mathrm{~B}_{0.15}\right)_{96} \mathrm{Nb}_{4}$ alloy rod with a diameter of $1.5 \mathrm{~mm}$ and nanocrystalline $\mathrm{Fe}_{73.5} \mathrm{Si}_{13.5} \mathrm{~B}_{9} \mathrm{Nb}_{3} \mathrm{Cu}_{1}$ (FINEMET) and $\mathrm{Fe}_{86} \mathrm{Zr}_{7} \mathrm{~B}_{6} \mathrm{Cu}_{1}$ (NANOPERM) alloy ribbons are also shown for comparison.

\begin{tabular}{lcccccc}
\multicolumn{1}{c}{ Alloy } & $t(\mu \mathrm{m})$ & Structure & $T_{\mathrm{a}}(\mathrm{K})$ & $T_{x 1}(\mathrm{~K})$ & $B_{\mathrm{s}}(\mathrm{T})$ & $\mu_{\mathrm{e}}(1 \mathrm{kHz})$ \\
\hline $\mathrm{Fe}_{72.5} \mathrm{Si}_{10} \mathrm{~B}_{12.5} \mathrm{Nb}_{4} \mathrm{Cu}_{1}$ (ribbon) & 40 & bcc & 883 & 841 & 1.23 \\
$\mathrm{Fe}_{72.5} \mathrm{Si}_{10} \mathrm{~B}_{12.5} \mathrm{Nb}_{4} \mathrm{Cu}_{1}$ (bulk) & 500 & bcc & 883 & 841 & 1.21 & 80000 \\
$\left(\mathrm{Fe}_{0.75} \mathrm{Si}_{0.1} \mathrm{~B}_{0.15}\right)_{96} \mathrm{Nb}_{4}$ (bulk) & 1500 & amorphous & 782 & 885 & 1.47 & 17000 \\
$\mathrm{Fe}_{73.5} \mathrm{Si}_{13.5} \mathrm{~B}_{9} \mathrm{Nb}_{3} \mathrm{Cu}_{1}$ (ribbon)** & 18 & bcc & 823 & 775 & 1.24 \\
$\mathrm{Fe}_{86} \mathrm{Zr}_{7} \mathrm{~B}_{6} \mathrm{Cu}_{1}$ (ribbon)*** & 21 & bcc & 873 & 792 & 1.52 \\
\hline
\end{tabular}

${ }^{*}$ Ref. 17), ${ }^{* *}$ Ref. 22), ${ }^{* * *}$ Ref. 25) 
32000. One can notice clearly the achievement of good soft magnetic properties in the nanocrystalline structure state even for the bulk alloy rod form. The $B_{\mathrm{s}}$ and $H_{\mathrm{c}}$ are nearly the same as those for the corresponding nanocrystalline alloy ribbon. However, the initial permeability of the nanocrystalline alloy rod is considerably smaller than that (80000) for the ribbon sample. The difference is presumably because of the influence of reversed magnetic field resulting from the rod shape. That is, as mentioned above, the shape of the rod sample is about $30 \mathrm{~mm}$ in length and $0.5 \mathrm{~mm}$ in diameter. In comparison with the ribbon sample with much larger length and much smaller thickness, the demagnetizing factor of the rod sample is much larger than that of the ribbon sample, resulting in the decrease of the initial permeability of the nanocrystalline alloy rod. It is further noticed that the $B_{\mathrm{s}}$ and $H_{\mathrm{c}}$ of the present nanocrystalline alloy are nearly the same as those for commercial nanocrystalline $\mathrm{Fe}-\mathrm{Si}-\mathrm{B}-\mathrm{Nb}-\mathrm{Cu}$ alloy ribbon (FINEMET) in spite of the significant change in alloy composition leading to the increase of the glass-forming ability.

\section{Discussion}

It has previously been described that the increase in the glass-forming ability of the $\mathrm{Fe}_{75} \mathrm{Si}_{10} \mathrm{~B}_{15}$ alloy by the addition of 2 to 4 at $\% \mathrm{Nb}$ is due to the enhancement of the thermal stability of supercooled liquid against crystallization and the increase in the reduced glass transition temperature $\left(T_{\mathrm{g}} / T_{1}\right)$ by the increase in $T_{\mathrm{g}}$ and the decrease in $T_{1} \cdot{ }^{17}$ ) The increase in the thermal stability of supercooled liquid has been demonstrated by the appearance of the glass transition phenomenon for the $\left(\mathrm{Fe}_{75} \mathrm{Si}_{10} \mathrm{~B}_{15}\right)_{100-x} \mathrm{Nb}_{x}$ alloys containing more than 2 at\% Nb. ${ }^{17)}$ However, as shown in Fig. 2, no glass transition was observed for the $\mathrm{Fe}_{72.5} \mathrm{Si}_{10} \mathrm{~B}_{12.5} \mathrm{Nb}_{4} \mathrm{Cu}_{1}$ alloy, accompanying the decrease in the maximum amorphous rod diameter from 1.5 to $0.5 \mathrm{~mm}$. It is concluded that the addition of $\mathrm{Cu}$ with a positive heat of mixing against $\mathrm{Fe}^{26}$ ) is harmful for stabilization of supercooled liquid against crystallization, in agreement with the previous concept on the stabilization of supercooled liquid. ${ }^{1-3)}$ In addition, another reason for the disappearance of the glass transition seems to result from the decrease in $\mathrm{B}$ content leading to the decrease in the numbers of the $\mathrm{Nb}-\mathrm{B}$ and $\mathrm{Fe}-\mathrm{B}$ atomic pairs with large negative values ${ }^{26}$ ) which have a dominant effect on the glass-forming ability of $\mathrm{Fe}-\mathrm{B}$ based alloys. However, it is noticed that despite the harmful influence of $\mathrm{Cu}$ and the decrease in $\mathrm{B}$ content, the amorphous alloy rod of $0.5 \mathrm{~mm}$ in diameter was produced for the $\mathrm{Fe}_{72.5} \mathrm{Si}_{10} \mathrm{~B}_{12.5} \mathrm{Nb}_{4} \mathrm{Cu}_{1}$ alloy.

We further discuss the reason for the formation of the amorphous alloy rod in the $\mathrm{Fe}-\mathrm{Si}-\mathrm{B}-\mathrm{Nb}-\mathrm{Cu}$ system. Figure 5 shows the DTA curves of the $\mathrm{Fe}_{75} \mathrm{Si}_{10} \mathrm{~B}_{15}$, $\left(\mathrm{Fe}_{0.75} \mathrm{Si}_{0.1} \mathrm{~B}_{0.15}\right)_{96} \mathrm{Nb}_{4}$ and $\mathrm{Fe}_{72.5} \mathrm{Si}_{10} \mathrm{~B}_{12.5} \mathrm{Nb}_{4} \mathrm{Cu}_{1}$ alloys. The liquidus temperature $\left(T_{1}\right)$ is determined as $1450 \mathrm{~K}$ for the $\mathrm{Fe}-\mathrm{Si}-\mathrm{B}$ alloy, $1374 \mathrm{~K}$ for the Fe-Si-B-Nb alloy and $1365 \mathrm{~K}$ for the $\mathrm{Fe}-\mathrm{Si}-\mathrm{B}-\mathrm{Nb}-\mathrm{Cu}$ alloy. Although no glass transition is observed for the $\mathrm{Fe}-\mathrm{Si}-\mathrm{B}-\mathrm{Nb}-\mathrm{Cu}$ alloy, it is noticed that the $T_{1}$ of the $\mathrm{Cu}$-containing alloy is the lowest and no primary precipitation reaction is seen. The lowest $T_{1}$ which is comparable to that for the $\mathrm{Fe}-\mathrm{Si}-\mathrm{B}-\mathrm{Nb}$ alloy as well as the nearly single solidification reaction is presumed to have enabled us to form the amorphous alloy rod for the $\mathrm{Fe}-\mathrm{Si}-\mathrm{B}-\mathrm{Nb}-\mathrm{Cu}$ al-

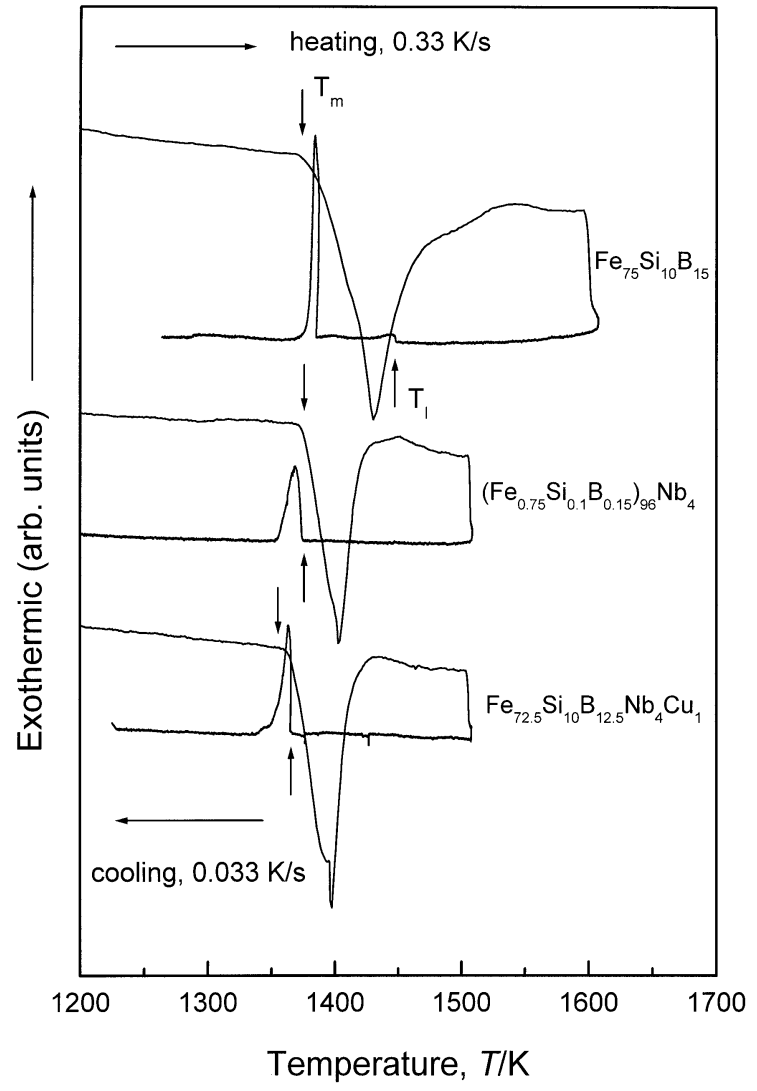

Fig. 5 DTA curves of $\mathrm{Fe}_{75} \mathrm{Si}_{10} \mathrm{~B}_{15}, \quad\left(\mathrm{Fe}_{0.75} \mathrm{Si}_{0.1} \mathrm{~B}_{0.15}\right)_{96} \mathrm{Nb}_{4}$ and $\mathrm{Fe}_{72.5} \mathrm{Si}_{10} \mathrm{~B}_{12.5} \mathrm{Nb}_{4} \mathrm{Cu}_{1}$ alloys.

loy, though the rod diameter is limited to less than $0.5 \mathrm{~mm}$. Considering the significant decrease in $T_{1}$ and the appearance of glass transition for the $\mathrm{Fe}-\mathrm{Si}-\mathrm{B}-\mathrm{Nb}$ alloys, the rather high glass-forming ability for the $\mathrm{Fe}-\mathrm{Si}-\mathrm{B}-\mathrm{Nb}-\mathrm{Cu}$ alloys seems to reflect the enhancement effect of $\mathrm{Nb}$ addition exceeding the harmful influence by the addition of $\mathrm{Cu}$ and the decrease in $\mathrm{B}$ content.

\section{Summary}

We examined the possibility of forming a nanocrystalline Fe-based bulk alloy exhibiting good soft magnetic properties. The results obtained are summarized as follows.

(1) An amorphous alloy rod of $0.5 \mathrm{~mm}$ in diameter was obtained in the $\mathrm{Fe}_{72.5} \mathrm{Si}_{10} \mathrm{~B}_{12.5} \mathrm{Nb}_{4} \mathrm{Cu}_{1}$ alloy by copper mold casting.

(2) The amorphous alloy rod exhibits multi-stage crystallization process in which the first stage is due to the precipitation of bcc-Fe phase and the following stages are attributed to the transition of bcc-Fe + amorphous to bcc-Fe $+\mathrm{Fe}_{23} \mathrm{~B}_{6}+$ $\mathrm{Fe}_{2} \mathrm{~B}+\mathrm{Fe}_{3} \mathrm{Si}+\mathrm{Fe}_{2} \mathrm{Nb}$ phases. The bcc-Fe phase has a very fine grain size of $10 \mathrm{~nm}$ and its volume fraction is about $70 \%$ after the completion of the first-stage precipitation reaction.

(3) The nanoscale mixed phase alloy consisting of bcc-Fe and remaining amorphous phases exhibited good soft magnetic properties, i.e., high $B_{\mathrm{s}}$ of $1.21 \mathrm{~T}$, low $H_{\mathrm{c}}$ of $1.8 \mathrm{~A} / \mathrm{m}$ and high $\mu_{\mathrm{i}}$ of 32000 .

The first synthesis of the nanocrystalline Fe-based alloy rod exhibiting good soft magnetic properties is expected to extend significantly the future application field as soft magnetic ma- 
terials.

\section{REFERENCES}

1) A. Inoue: Bulk Amorphous Alloys, (Trans Tech Publications, Zurich, 1999) pp. 1-148.

2) A. Inoue: Acta Mater. 48 (2000) 279-306.

3) A. Inoue: Mater. Sci. Eng. A304-306 (2001) 1-10.

4) A. Inoue, A. Takeuchi and B. L. Shen: Mater. Trans. 42 (2001) 970-978.

5) A. Inoue, Y. Shinohara and J. S. Gook: Mater. Trans., JIM 36 (1995) 1427-1433.

6) A. Inoue and J. S. Gook: Mater. Trans., JIM 37 (1996) 32-38.

7) B. L. Shen, H. Koshiba, T. Mizushima and A. Inoue: Mater. Trans., JIM 41 (2000) 873-876.

8) T. D. Shen and R. B. Schwarz: Appl. Phys. Lett. 75 (1999) 49-51.

9) B. L. Shen, H. Koshiba, H. Kimura and A. Inoue: Mater. Trans., JIM 41 (2000) 1478-1481.

10) B. L. Shen, H. M. Kimura, A. Inoue and T. Mizushima: Mater. Trans., JIM 41 (2000) 1675-1678.

11) H. Koshiba, A. Inoue and A. Makino: J. Appl. Phys. 85 (1999) 51365138.

12) A. Inoue, T.Zhang, H. Koshiba and A. Makino: J. Appl. Phys. 83 (1998) 6326-6328.
13) W. Zhang and A. Inoue: Mater. Trans. 41 (2000) 1679-1682.

14) S. J. Pang, T. Zhang, K. Asami and A. Inoue: Acta Mater. 50 (2002) 489-497.

15) S. J. Pang, T. Zhang, K. Asami and A. Inoue: Mater. Trans. 42 (2001) 376-379.

16) T. D. Shen and R. B. Schwarz: Acta Mater. 49 (2001) 837-847.

17) A. Inoue and B. L. Shen: Mater. Trans. 43 (2002) 766-769.

18) A. Inoue and B. L. Shen: Mater. Trans. (to be submitted).

19) A. Inoue, T. Zhang and A. Takeuchi: Appl. Phys. Lett. 71 (1997) 464466.

20) W. Zhang and A. Inoue: Mater. Trans. 42 (2001) 1835-1838.

21) B. L. Shen and A. Inoue: Mater. Trans. 43 (2002) 1235-1239.

22) Y. Yoshizawa, S. Oguma and K. Yamauhi: J. Appl. Phys. 64 (1988) 6044-6046.

23) K. Hono, A. Inoue and T. Sakurai: Appl. Phys. Lett. 58 (1991) 21802182.

24) K. Hono, K. Hiraga, A. Inoue and T. Sakurai: Acta Mater. 40 (1992) 2137-2147.

25) A. Makino, K. Suzuki, A. Inoue and T. Masumoto: Mater. Trans., JIM 32 (1991) 551-556.

26) F. R. Niessen: Cohesion in Metals, (Elsevier Science Publishers, B.V., Amsterdam, 1988) pp. 224-391. 